\title{
Letter to editor:Obituary
}

\section{Musa M. Nordin', AA Misha' $l^{2}$}

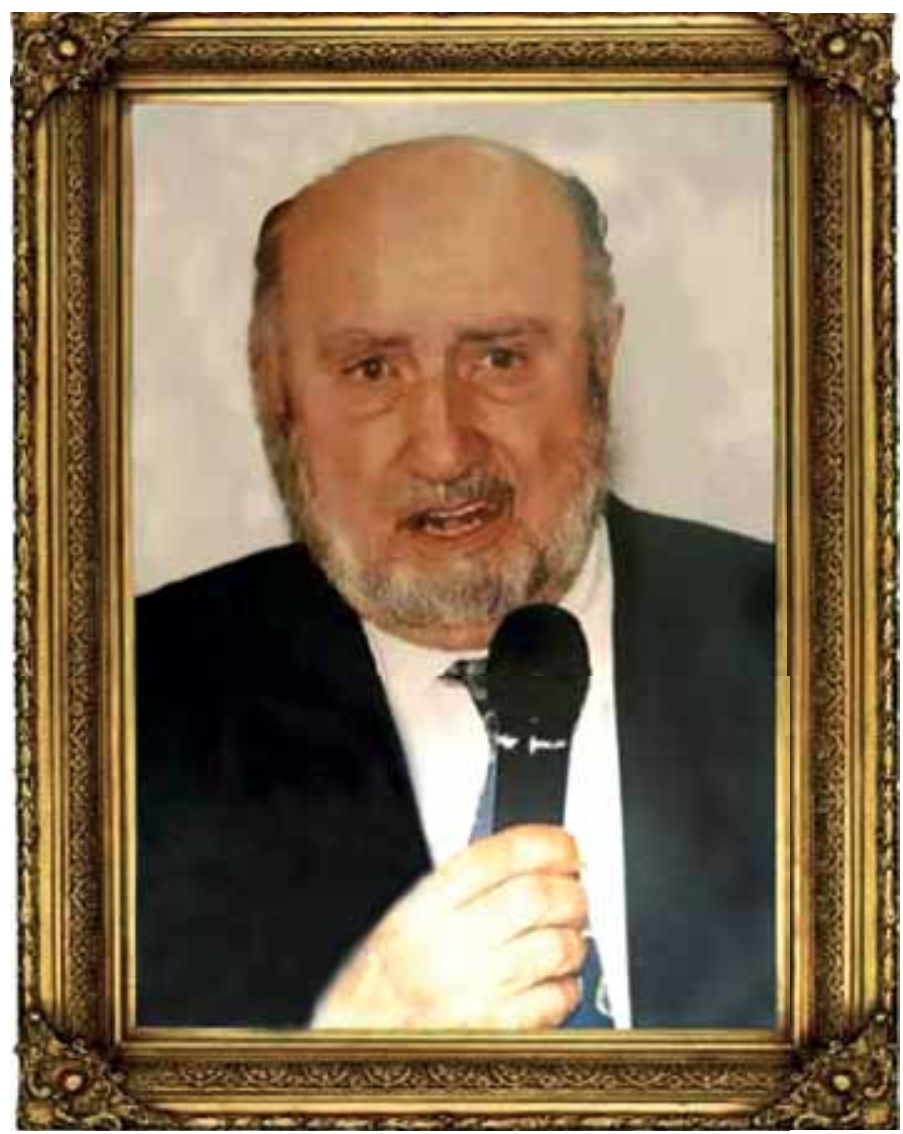

Al-Marhum Dr Ali El-Hawamdeh

(1932 - 2017)

International Journal of Human and Health Sciences Vol. 01 No. 01 January'17. Page : 48-50

Born in Karak, Jordan in 1932, Dr Hawamdeh graduated from Cairo Medical College, Egypt in 1957.

He practised medicine in the Ministry of Health, Jordan, before operating his private clinic.

On August 15, 1984, the Board of Directors of the Islamic Hospital in Jordan selected him as the Director General of the Hospital. He performed his duties as Director General until 2002 when he retired at the age of 70 .

Under his tenure of 18 years, the Islamic Hospital grew steadily in all dimensions, and became the largest hospital in the private sector, and the first to be accredited for specialty residency training in Jordan.

In 1988, he received a special invitation from the president of the Islamic International Council for Da'awa \& Relief (IICDR) to become a member of the first General Assembly of the Council. He was the FIMA representative on IICDR for 10 years. In 1989, he was elected as a Member of Parliament in Jordan, for 4 years. He conducted this major political task in addition to his responsibilities as Director General of the Islamic Hospital. Dr. Hawamdeh donated all his salaries from Parliament to the Islamic Hospital.

1. Aly Mishal, Ex-Executive Director, Islamic Hospital, Amman, Jordan

2. Musa Mohd. Nordin, Professor, Cyberjaya University College of Medical Sciences, Malaysia.

Correspondence to: Musa Mohd. Nordin, Professor, Cyberjaya University College of Medical Sciences, Malaysia.email: musamn@gmail.com 
Dr. Hawamdeh was elected as FIMA Secretary and Treasurer during the $4^{\text {th }}$ FIMA Council meeting on January 3-5, 1987 in Amman, Jordan. Dr. Hawamdeh enhanced the vision and mission of FIMA and directed the capabilities of the Islamic Hospital (IH) for the global FIMA cause.

The secretarial and communication facilities of IH were put at the service of FIMA. He and the IH extended hospitality to delegations from various IMAs, individuals and groups, towards nurturing brotherhood, understanding and collaboration between Muslim medical practitioners and expanding the membership of FIMA.

With the support of the Board of Directors, Dr Hawamdeh directed the financial support of many of FIMA's activities during its early formative years. The Islamic Hospital in Jordan doubled its annual dues to further support FIMA activities.

Under his dynamic leadership, the IH in Jordan became the epicenter of FIMA activism. Delegations from all over the world, representing IMAs, relief organizations and other Islamic medical, charitable and social groups, were received and hosted by the IH.

Muslim medical students from all over the world, especially those selected by their respective IMAs, came to the IH for their elective training. They were received, housed, trained, and orientated with the Islamic ethos by qualified IH medical and health professionals.

Medical doctors and trainees in various medical fields came to the Islamic Hospital, for their specialty and sub-specialty training and to enhance their knowledge, skills and experiences.

Many Islamic hospitals from various countries sent delegations to the $\mathrm{IH}$ to benefit from its experiences in specific areas of hospital administration, operations, management and accreditation which are Shari'ah compliant.

Under his leadership, the IH actively participated in various relief campaigns conducted by FIMA in countries afflicted by disasters.

Dr Hawamdeh served diligently as both FIMA Secretary and Treasurer for 10 years until 1997. $\mathrm{He}$ continued his executive position as FIMA treasurer for 18 years until June 2005 at the FIMA Council meeting in Sana'a, Yemen.

In 2002, at the age of 70, Dr Hawamdeh retired as Director General of the $\mathrm{IH}$, but continued his services as the FIMA treasurer until 3 years later. Dr Hawamdeh hosted and honored virtually all the FIMA delegations in his home and showered them with his undivided and generous hospitality. $\mathrm{He}$ personally received them on arrival, accompanied them on their sight-seeing trips, fed them well and bid them farewell on their return. All this with his warm loving heart, always smiling and joking, which made us all felt at ease and loved him ever so much. He was like a loving grandfather to the many medical students and trainees, a father and mentor to many of us physicians and specialists and a genuine friend to his peers, the likes of Dr Aly Mishal, Dr Adnan Jaljuli, Dr Mohamed Khan, Dr Ghulam Hoosen, Dr Jurnalis Uddin, Dr Syed Mubin Akhter et al.

For his outstanding and unparalleled contributions to the advancement of the ideals of FIMA, he was awarded the FIMA Lifetime Achievement Award in 2007, at the FIMA and Hayat Foundation Gala Dinner during the $24^{\text {th }}$ FIMA Council Meeting in Istanbul, Turkey. With the background information provided by Syakh Dr Aly Mishal, I as the president of FIMA then, had the honor of reading his remarkable citation during this most prestigious celebration.

On August 23 $3^{\text {rd }}, 2017$, Dr Ali Passed away to the folds of mercy and blessings of his creator.

O Allah! We beseech You to bestow Your bountiful and infinite blessings on our father, Dr Ali ElHawamdeh, for all his spirited, persistent and untiring services to Your Deen.

O Allah! Specifically, bless our father, Dr Ali El Hawamdeh for his dynamic, energetic and excellent leadership of FIMA, in her formative years and its evolution now into an organization which is respected and revered globally in the realm of healthcare services, education, research and main-streaming the Islamic perspectives of medical ethics.

O Allah! Bless our father Dr Ali El-Hawamdeh, for teaching and training us the art of generosity by mobilizing all the resources at his disposal for the betterment of FIMA and now FIMA is one of the leaders of medical and humanitarian relief for the mercy and healing of mankind.

O Allah! Bless and forgive our father Dr Ali ElHawamdeh, we beseech that You accept all his efforts as pure deeds to only seek Your Mardatillah (pleasure).

"To the righteous it will be said: "O peaceful and fully satisfied soul, return to your Lord.You are well-pleased (with your good end) and wellpleasing (in the sight of your Lord). Join My (righteous) servants and enter My Paradise." (A1 Fajr 27-30)

Humbly submitted

1. Prof. Musa Mohd Nordin

2. Prof Aly A. Misha'1 